\title{
LONG-TERM PLANT COMMUNITY DEVELOPMENT ON TOPSOIL TREATMENTS OVERLYING A PHYTOTOXIC GROWTH MEDIUM
}

\author{
Russell S. Sydnor \\ Bitterroot Restoration, Inc. \\ Auburn, CA \\ Edward F. Redente \\ Department of Rangeland Ecosystem Science \\ Colorado State University \\ Fort Collins, $\mathrm{CO}$
}

\begin{abstract}
The application of topsoil over phytotoxic mine waste materials is often the most effective method of establishing and maintaining plant communities during reclamation. However, long-term data on the effectiveness of topsoil cover treatments, as well as on treatments used to enhance vegetation establishment on soil covers, are lacking. Therefore, we evaluated long-term plant community development on study plots in which $60 \mathrm{~cm}$ of Paraho retorted oil shale was covered by various depths of topsoil. Each plot was drill seeded with one of three seed mixtures (native, introduced, and combination of native and introduced species), and fertilized with one of three rates of nitrogen (N) and phosphorus (P) fertilizer following plot construction in 1977. Data collected in 1997 showed that native species were as productive as introduced species on deeper topsoil depths and on the control. Also, relative plant species composition and plant species richness continued to be greatly influenced by seed mixture treatments. Plots seeded with a particular seed mixture were still dominated by those species originally seeded, and native seed mixture plots were more species rich than introduced seed mixture plots. Finally, the onetime application of $\mathrm{N}$ and $\mathrm{P}$ was no longer influencing aboveground biomass.
\end{abstract}

\section{INTRODUCTION}

Mining activities that produce phytotoxic waste materials occur throughout the western USA. Elevated concentrations of certain salts and trace elements in mine waste materials, and the movement of these elements via capillary rise, leaching, diffusion, and plant uptake and cycling (biocycling), may hinder reclamation efforts by inhibiting the satisfactory establishment of vegetation (Stark and Redente, 1990). In order to protect establishing plant communities from the upward movement of salts and trace elements, several researchers have advocated the placement of topsoil over such phytotoxic waste materials as retorted oil shale (Harbert and Berg, 1978; Harbert et al., 1979; Redente et al., 1982; Redente et al., 2000; Sydnor and Redente, 2000), trona tailings (Barth and Martin, 1981), molybdenum mill tailings (Trlica et al., 1994), and alumina refinery wastes (Bell and Meecham, 1978). In addition, many mining reclamation laws throughout the western USA require salvage and replacement of topsoil and the establishment of diverse, self-sustaining plant communities following reclamation. To date, much of the research that has focused on topsoil coverings over phytotoxic mine waste materials, and the cultural methods used to enhance vegetation establishment, productivity, and diversity, has studied treatment effects over short 
time scales (i.e., less than five years). Long-term reclamation research does exist but has mostly been conducted on topsoil treatments overlying non-phytotoxic mine spoils (Chambers et al., 1994; Redente $e t$ al., 1997) and on intensively disturbed soils associated with mining activity (Newman and Redente, 2001). As a consequence, long-term plant community development on topsoil treatments overlying phytotoxic mine waste materials is poorly understood. Thus, it is difficult to make recommendations on the reclamation of phytotoxic waste materials that will promote diverse and self-regenerating plant communities over longer time scales.

These deficiencies in research led us to revisit the Retorted Shale Successional Study (RSSS), which was established in 1977 and described by Redente et al. (1982). The objectives of the current study were 1) to evaluate the effects of topsoil, seed mixture, and fertilization treatments on plant community development after 20 growing seasons, and 2) to determine if soluble salts and trace elements have migrated from retorted oil shale layers into overlying topsoil. Results pertaining to Objective 1 are presented in this paper, whereas results relating to Objective 2 have been reported previously (Sydnor and Redente, 2000). Results of this study should prove useful in the reclamation of phytotoxic materials that may require soil covers for successful reclamation.

\section{MATERIALS AND METHODS}

This study was conducted in the Piceance Creek Basin of northwestern Colorado in Rio Blanco county $\left(39^{\circ} 54^{\prime} 13^{\prime \prime} \mathrm{N}, 108^{\circ} 24^{\prime} \mathrm{02}\right.$ ' W) approximately $65 \mathrm{~km}$ northwest of Rifle, CO. The study plots are situated on level ground at an average elevation of $2020 \mathrm{~m}$. The climate of the area is semi-arid. Mean annual precipitation (MAP) is $282 \mathrm{~mm}$; winter and spring (November-April) precipitation contributes roughly half of MAP, and is received mainly as snow. Mean annual temperature (MAT) is approximately $6.8^{\circ} \mathrm{C}$. Temperatures can often reach a maximum of $38^{\circ} \mathrm{C}$ in the summer and a minimum of $-40^{\circ} \mathrm{C}$ during winter months.

The study area was classified within the Mid-Elevation Big Sagebrush/ Moderately Deep Loams Phytoedaphic Unit as described by Tiedeman and Terwilliger (1978). Big sagebrush (Artemisia tridentata var. tridentata Nutt.) is the dominant species in undisturbed plant communities. Common understory species include: prairie junegrass (Koeleria macrantha (Ledeb.) J.A. Schultes), needle-and-thread (Stipa comata Trin. \& Rupr.), carpet phlox (Phlox hoodii Richards.), scarlet globemallow (Sphaeralcea coccinea (Pursh) Rydb.), and prickly pear cactus (Opuntia polycantha Haw.). Native reference plots adjacent to the study were found to support approximately $150 \mathrm{~g} \mathrm{~m}^{-2}$ of aboveground biomass averaged over a four year period (McLendon and Redente, unpublished data). Loamy soils of the Yamac series (mixed Borollic Camborthids) are common in the vicinity of the study site (Mount, 1985). Depth to bedrock is highly variable on these soils and averages approximately $50 \mathrm{~cm}$ (Redente $e t$ al., 1982).

The RSSS was initiated in the summer of 1977 to examine three main treatments common in the reclamation of retorted oil shale with respect to their effects on plant establishment and succession, and to determine the movement of trace elements and salts contained in soil-covered retorted oil shale. The study was established as a split-split plot design with 5 topsoil treatments (whole plot treatment), 3 seed mixtures (subplot treatment), 3 fertilizer treatments (sub-subplot treatment), and 3 replications. A total of 135 study plots (experimental units) were established with each measuring $7 \times 11.5 \mathrm{~m}$. It should be noted that the three seed mixtures and three fertilizer treatments were truly replicated throughout the study; 

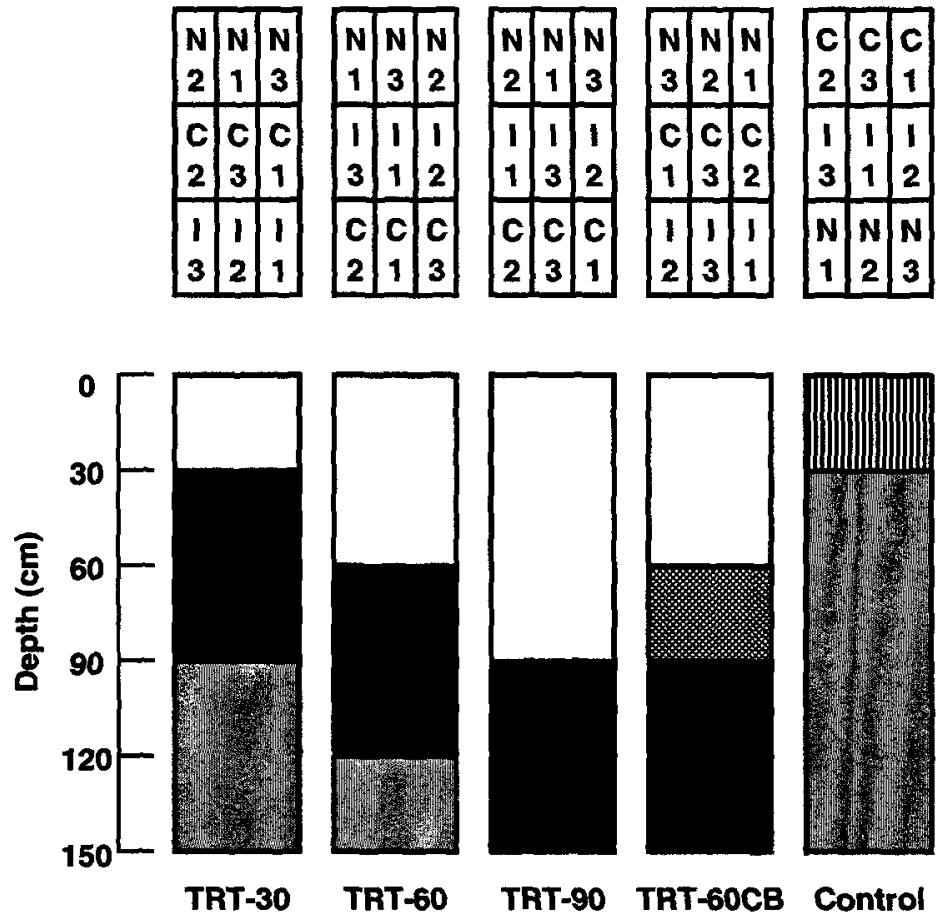

Figure 1. Overhead view of the experimental layout of study plots (top) and side view of topsoil treatments (bottom). Only one replication is shown for study plot layout.

however, since logistics required long, continuous pits in the construction of the topsoil treatments, these treatments were pseudoreplicated.

Topsoil used in this study was obtained on-site during the construction of the experiment, and the retorted oil shale (produced by the Paraho method) originated from the Anvil Points retorting facility near Rifle, CO. In all topsoil treatments except the control, a $60 \mathrm{~cm}$ layer of retorted oil shale was placed at an appropriate depth such that the surface of the various topsoil treatments would be level with the existing soil grade. Also, the lower $15 \mathrm{~cm}$ of the $60 \mathrm{~cm}$ layer of retorted shale was compacted to limit the percolation of soil water through the shale. The five topsoil treatments included:

1. $30 \mathrm{~cm}$ of topsoil over retorted shale (TRT-30).

2. $60 \mathrm{~cm}$ of topsoil over retorted shale (TRT-60).

3. $90 \mathrm{~cm}$ of topsoil over retorted shale (TRT-90).

4. $60 \mathrm{~cm}$ of topsoil over $30 \mathrm{~cm}$ rock capillary barrier over retorted shale (TRT-60CB).

5. Soil control without retorted shale which involved mechanically removing vegetation and ripping remaining soil to a depth of $30 \mathrm{~cm}$ (Control).

A visual representation of topsoil treatments and the experimental layout of study plots is presented (Figure 1).

Each topsoil treatment was then drill seeded with three different seed mixtures in November of 1977 . The seed mixtures consisted of a diverse mixture of either all native, all introduced, or a combination of native and introduced grasses, forbs, and shrubs (Sydnor and Redente, 2000). In addition, three fertilizer treatments were applied: 1) $112 \mathrm{~kg} \mathrm{~N} / \mathrm{ha}, 56 \mathrm{~kg} \mathrm{P} / \mathrm{ha}, 2) 56 \mathrm{~kg} \mathrm{~N} / \mathrm{ha}, 28 \mathrm{~kg} \mathrm{P} / \mathrm{ha}$, and 3) a control 
consisting of no fertilization. Phosphorus was applied as triple superphosphate (0-46-0) prior to seeding and was incorporated into the soil using a tractor-mounted rototiller to a depth of $30 \mathrm{~cm}$. The application of $\mathrm{N}$, in the form of ammonium nitrate (33-0-0), did not occur until the end of the first growing season (1978) in an attempt to limit the invasion of weedy annual plant species (Mount, 1985).

During June and July of 1997, we sampled each of the 135 study plots for aboveground biomass by harvesting vegetation within randomly placed $0.5 \mathrm{~m}^{2}$ quadrats. Six quadrats were sampled within each study plot. Plants within the quadrat volume were clipped at ground level and separated by species. Plant samples were oven-dried at $55^{\circ} \mathrm{C}$ for 48 hours and then weighed to determine aboveground biomass.

Vegetation data were analyzed using a three-way analysis of variance (SAS Institute, 1998). The dependent variable was aboveground biomass $\left(\mathrm{g} \mathrm{m}^{-2}\right)$, whereas independent variables included topsoil depth, seed mixture, and fertilization rate. The three main treatment effects, as well as any interactions, were tested for significance within grass, forb, shrub, and total aboveground biomass at the $\alpha=0.05$ level. Means separation tests were performed using LSD at the $\alpha=0.05$ level. The most important independent variables included topsoil and seed mixture treatments, as well as the interaction between these two variables. Fertilization rate, represented by the one-time application of $N$ and $P$ in 1978, was no longer significant; therefore, this treatment will not be discussed in further sections of this paper.

\section{RESULTS AND DISCUSSION}

\section{Effect of topsoil depth}

After 20 years of plant community development, variations in topsoil depth (when averaged over seed mixture treatments) continued to influence total aboveground biomass. Overall, deeper topsoil depths supported greater aboveground biomass, being greatest on TRT-60CB $\left(139 \mathrm{~g} \mathrm{~m}^{-2}\right)$ and TRT-90 (131 $\mathrm{g} \mathrm{m}^{-}$ ${ }^{2}$ ), and lowest on TRT-30 (116 $\left.\mathrm{g} \mathrm{m}^{-2}\right)$, TRT-60 (116 $\left.\mathrm{g} \mathrm{m}^{-2}\right)$, and the control $\left(102 \mathrm{~g} \mathrm{~m}^{-2}\right)$ (Figure 2). Increased productivity of grasses, especially on TRT-60CB, was mostly responsible for greater total aboveground biomass on deeper topsoil depths (Figure 2). Forb and shrub biomass did not respond as consistently to variations in topsoil depth, but both were generally lowest on TRT-60CB and the control (Figure 2). 


\section{GGrass Dorb GShrub}



Figure 2. Mean aboveground biomass $\left(\mathrm{g} \mathrm{m}^{-2}\right)$ by topsoil treatment. Each mean for a given life form or total value within a topsoil treatment represents data taken from 27 plots $(n=27)$. Comparisons are made within each life form or the total of all three life forms across topsoil treatments. Means with the same letter within life forms or the total of all three life forms are not significantly different $(\alpha=0.05)$.

The depth of topsoil needed to maximize aboveground biomass on reclaimed mined land has been widely studied (Harbert and Berg, 1978; Bell and Meecham, 1978; Power et al., 1981; Redente et al., 1982; Barth, 1983; Schuman et al., 1985; Trlica et al., 1994; Redente et al., 1997). In general, these authors reported that productivity increased, especially with respect to grass biomass, as topsoil depth increased. The topsoil depth at which aboveground biomass is maximized is site-specific (Schuman and Power, 1981), and depends greatly upon (in order of importance) the characteristics of the underlying mine waste material, regional climatic conditions, and topsoil quality (Hargis and Redente, 1984). With respect to the characteristics of the waste material to be covered, Hargis and Redente (1984) recommended that deeper depths of topsoil are necessary when underlying mine waste or spoil material is phytotoxic, as compared to non-phytotoxic materials. In support of this statement, Barth (1983) found that the productivity of perennial grasses was maximized on the following topsoil depths over mine spoils (with chemical characteristics of spoil in parentheses): $50 \mathrm{~cm}$ (slightly saline), $71 \mathrm{~cm}$ (sodic), and more than $100 \mathrm{~cm}$ (acidic). In contrast, Schuman et al. (1985) reported that $40 \mathrm{~cm}$ of topsoil overlying non-toxic spoil from a uranium mine supported equal amounts of aboveground biomass as did $60 \mathrm{~cm}$ of topsoil. Likewise, Redente et al. (1997) reported that $15 \mathrm{~cm}$ of topsoil overlying non-phytotoxic coal spoil supported as much total aboveground biomass as $60 \mathrm{~cm}$ of topsoil. Deeper depths of topsoil overlying phytotoxic waste materials apparently benefit plant communities by isolating plant roots from the inimical properties of mine waste materials and limiting the upward movement of salts and trace elements (Barth, 1988). 
Despite supporting equal amounts of aboveground biomass, relative production of grasses on TRT-60CB plots was approximately $25 \%$ greater than on TRT- 90 plots. Furthermore, the relative production of forbs and shrubs on TRT-90 plots was nearly twice as great when compared to TRT-60CB plots (Sydnor, 1999). Relative production of grasses, forbs, and shrubs on TRT-60CB plots may have been influenced by the physical presence of the capillary barrier. Redente and Cook (1984) hypothesized that the abrupt textural change at the topsoil/capillary barrier interface disrupted the downward movement of soil water on TRT-60CB plots during the first six growing seasons (1978-1983), leading to greater soil moisture in topsoil overlying the barrier and more favorable growth conditions, especially for grasses. Upon examination of the capillary barrier in 1997, we observed that the large pore spaces that once existed in the rock barrier have filled with soil since the 1983 growing season. However, Barth (1988) suggested that large rocks present in capillary barriers, even when void areas within these barriers are filled with soil particles, may continue to disrupt the movement of soil water by interrupting pore continuity of soil present in the capillary barrier. Thus, the downward movement of soil water through the capillary barrier may still be obstructed, leading to greater soil moisture in overlying topsoil, and helping to explain the continued dominance of grass species on TRT-60CB plots relative to the other topsoil treatments (Figure 2).

Effect of seed mixtures

Barth (1986) stated that many of the plant species used to revegetate disturbed areas should be transitory and that their use should not compromise secondary successional processes by preventing or hindering the establishment of colonizing, non-seeded species. However, our long-term data revealed that study plots seeded with a given seed mixture in 1977 have tended to remain dominated by those species originally seeded (Sydnor and Redente, 2000). Other long-term studies have reported similar findings 14 to 23 years after seeding (Jordan and Dewar, 1985; Chambers et al., 1994; Walker et al., 1995; Newman and Redente, 2001). Furthermore, in support of our study, these same authors reported that the colonization of native, non-seeded species (especially shrubs) was slow in the presence of introduced species, possibly due to competition with introduced grasses. For example, colonizing, non-seeded native shrubs contributed 1\% of total production in the introduced seed mixture in 1983 (Redente and Cook, 1984), and by 1997 were contributing only 3\% (Sydnor, 1999); conversely, colonizing, non-seeded native shrubs only represented a trace amount of total production in 1983 on plots seeded with the native mixture (Redente and Cook, 1984), but contributed 8\% of total production by 1997 on these same plots (Sydnor, 1999). Given that seeded species were initially favored by a well-prepared seedbed, we feel that the longterm dominance of seeded species has been maintained over time by interspecific competition among these species for limited resources, which has slowed the colonization of non-seeded species.

Our results also indicated that the choice of seed mixture may affect the long-term productivity of restored plant communities. In the current study, the introduced seed mixture $\left(134 \mathrm{~g} \mathrm{~m}^{-2}\right)$ supported greater aboveground biomass than either the native $\left(120 \mathrm{~g} \mathrm{~m}^{-2}\right)$ or combination $\left(108 \mathrm{~g} \mathrm{~m}^{-2}\right)$ seed mixtures, when averaged over topsoil depth (Figure 3). This result contradicts Newman and Redente (2001) who found that a native seed mixture was more productive than an introduced seed mixture after 21 growing seasons; this response was partially due to the effects of an initial, two-year irrigation treatment. However, when we considered variations in topsoil depth, we found that the native seed mixture was as productive as the introduced seed mixture on deeper topsoil depths (TRT-60CB and TRT-90) and the control (Table 1); conversely, the introduced seed mixture was more productive than both the native and combination mixtures on shallow topsoil depths. This trend suggests that the use of a native seed mixture may result in a plant community as productive as one resulting from a seed mixture containing all 
introduced species, over longer time scales, when well isolated from a phytotoxic growth medium (i.e., with the use of deeper topsoil depths). Overall, the results of this study indicate that the selection of a seed mixture for reclamation projects may have long-lasting effects on the resulting plant community in terms of plant species composition and productivity.

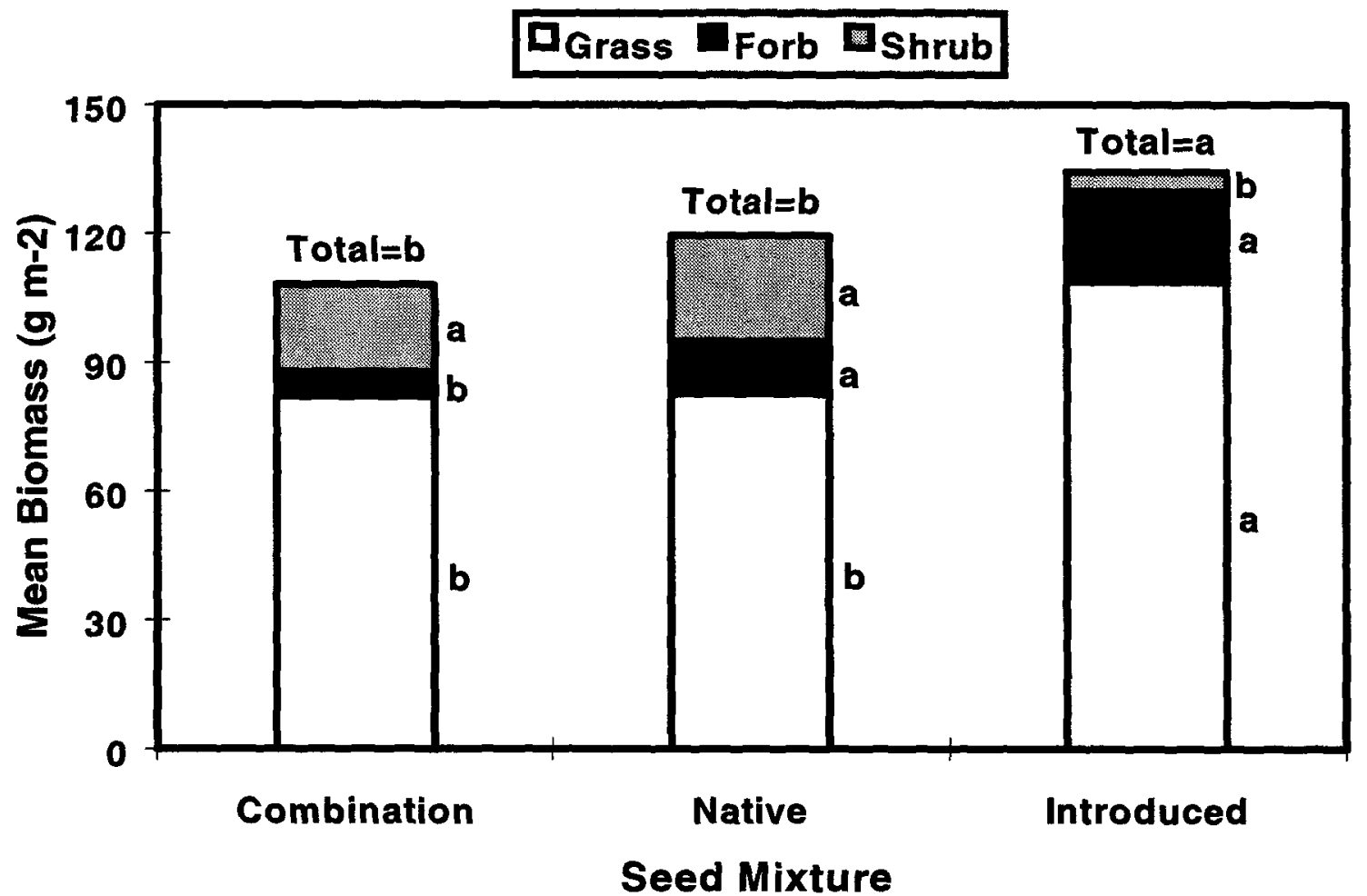

Figure 3. Mean aboveground biomass $\left(\mathrm{g} \mathrm{m}^{-2}\right)$ by seed mixture. Each mean for a given life form or total value within a seed mixture represents data taken from 27 plots $(n=27)$. Comparisons are made within each life form or the total of all three life forms across topsoil treatments. Means with the same letter within life forms or the total of all three life forms are not significantly different $(\alpha=0.05)$.

Effect of treatments on plant species richness

Overall, changes in topsoil depth did not affect plant species richness. This result contradicts Huston's (1979) hypothesis concerning the relationship between diversity (which included the concepts of species richness and evenness) and productivity: "[d]iversity is determined not so much by the relative competitive abilities of the competing species as by the influence of the environment on the net outcome of their interactions." Put another way, conditions that enhance the rate at which certain plant species' competitive abilities are expressed will tend to lower diversity (or richness) as less competitive species are excluded. However, on deeper topsoil treatments, the increased productivity of grasses did not appear to heighten competitive exclusion of other species or limit colonization of species from the neighboring species pool. 
Despite the fact that the introduced seed mixture was generally the most productive in the current study, this mixture had the lowest species richness. Overall, plots seeded with the introduced mixture contained

Table 1. Mean aboveground biomass $\left(\mathrm{g} \mathrm{m}^{-2}\right)$ by life form within a given seed mixture and topsoil treatment. Each mean represents data taken from nine plots $(n=9)$. Comparisons are made within each life form (and the total of all three life forms) and are among seed mixtures. Values followed by the same letter within a column are not significantly different $(\alpha=$ 0.05 ).

\begin{tabular}{|c|c|c|c|c|c|}
\hline \multirow[b]{2}{*}{$\begin{array}{l}\text { Life form within } \\
\text { seed mixture }\end{array}$} & \multicolumn{5}{|c|}{ Topsoil Treatment } \\
\hline & TRT-30 & TRT-60 & TRT-90 & TRT-60CB & Control \\
\hline Native & $g m^{-2}$ & $g m^{-2}$ & $g m^{-2}$ & $g m^{-2}$ & $g m^{-2}$ \\
\hline $\begin{array}{l}\text { Grass } \\
\text { Forb } \\
\text { Shrub }\end{array}$ & $\begin{array}{l}61 \mathbf{b} \\
13 \mathbf{a} \\
28 \mathbf{a} \\
\end{array}$ & $\begin{array}{l}67 \mathrm{c} \\
17 \mathrm{a} \\
21 \mathrm{a} \\
\end{array}$ & $\begin{array}{c}78 \mathbf{b} \\
13 \mathbf{a b} \\
38 \mathbf{a} \\
\end{array}$ & $\begin{array}{c}113 \mathbf{b} \\
11 \mathbf{a} \\
22 \mathrm{a} \\
\end{array}$ & $\begin{array}{c}94 \mathbf{a} \\
7 \mathbf{a} \\
15 \mathbf{a b} \\
\end{array}$ \\
\hline TOTAL & $102 b$ & $105 b$ & $129 a$ & 145a & $116 a$ \\
\hline $\begin{array}{l}\text { Introduced } \\
\text { Grass } \\
\text { Forb } \\
\text { Shrub }\end{array}$ & $\begin{array}{r}102 a \\
32 \mathbf{a} \\
11 \mathbf{b} \\
\end{array}$ & $\begin{array}{c}110 \mathbf{a} \\
25 \mathbf{a} \\
2 \mathbf{b} \\
\end{array}$ & $\begin{array}{c}109 a \\
31 \mathbf{a} \\
7 \mathbf{b} \\
\end{array}$ & $\begin{array}{c}132 \mathbf{a} \\
10 \mathbf{a b} \\
0 \mathbf{b} \\
\end{array}$ & $\begin{array}{c}90 a \\
7 a \\
4 b \\
\end{array}$ \\
\hline TOTAL & $145 a$ & $137 \mathbf{a}$ & $147 a$ & $142 a$ & 101ab \\
\hline $\begin{array}{l}\text { Combination } \\
\text { Grass } \\
\text { Forb } \\
\text { Shrub }\end{array}$ & $\begin{array}{l}62 b \\
11 a \\
26 a \\
\end{array}$ & $\begin{array}{c}84 b \\
2 b \\
19 a \\
\end{array}$ & $\begin{array}{c}86 b \\
8 b \\
24 a \\
\end{array}$ & $\begin{array}{c}111 b \\
1 c \\
17 a \\
\end{array}$ & $\begin{array}{c}68 b \\
7 a \\
15 a \\
\end{array}$ \\
\hline TOTAL & $99 b$ & $105 b$ & $118 a$ & $128 \mathbf{a}$ & $90 \mathrm{~b}$ \\
\hline
\end{tabular}

an average of 2.7 species $\mathrm{m}^{-2}$, whereas native and combination seed mixture plots supported an average of 4.3 and 3.7 species $\mathrm{m}^{-2}$, respectively (Sydnor, 1999); as a comparison, undisturbed reference plots adjacent to the study site were found to contain 5.6 species $\mathrm{m}^{-2}$, on average (McLendon and Redente, unpublished data). In support of the current study, Redente et al. (1984) reported that seed mixtures containing all introduced species were generally less diverse than native seed mixtures, based on the Shannon-Weiner index. There may be several reasons why species richness or diversity is generally lower on sites seeded with introduced species mixtures. The most plausible explanation for this phenomenon in the current study may be attributed to the lack of introduced shrub establishment during the initial phases of this study (Redente et al., 1982). Thus, competition between introduced shrubs and grasses for resources on introduced seed mixture plots was non-existent during early plant community development. This lack of competition, coupled with favorable growing conditions for several of the introduced grasses, probably enhanced the growth rates and competitive abilities of introduced grasses, thus allowing them to dominate the introduced mixture, exclude other less competitive species, and lower species richness (Huston, 1979). 
The reclamation of mined lands in the western USA must achieve specific goals in terms of total production and plant species diversity; however, research has shown that productive, yet diverse plant communities are difficult to re-create (DePuit, 1984; Stark and Redente, 1985; Biondini and Redente, 1986). Some authors have successfully obtained both by increasing the number of species in an all-native seed mixture (DePuit and Coenenberg, 1979), or by using irrigation to manipulate composition of the seeded community (Redente and DePuit, 1988). Other authors (DePuit, 1984; Stark and Redente, 1985) have suggested the application of various depths of topsoil across the landscape as a potential strategy for obtaining productive and diverse plant communities. The results of the current study indicate that productive and relatively species-rich native plant communities can be established and maintained over phytotoxic mine waste materials with the use of at least $30 \mathrm{~cm}$ of topsoil, a diverse seed mixture of native species, and no initial fertilization. In addition, deeper topsoil coverings may be used to increase the productivity of a native seed mix without compromising plant species richness.

\section{CONCLUSIONS}

The lack of long-term data on the effectiveness of treatments used in the reclamation of phytotoxic waste materials is apparent in the literature. In an attempt to fill this void of knowledge, the current study shows that initial treatments may have long-lasting effects on the productivity, species composition, and plant species richness of plant communities 20 years after establishment. For example, the use of topsoil overlying retorted oil shale has resulted in plant communities that are as or more productive than the control, depending on the depth of topsoil used. Also, the long-term maintenance of native, species-rich plant communities may be achieved on topsoil treatments by initially seeding with a diverse mixture of native species. Thus, productive and species-rich native plant communities may be supported over longer time scales with the use of a topsoil covering over a phytotoxic mine waste material, a native seed mixture, and no initial fertilization. However, if greater productivity or increased isolation of plant roots from waste materials is a goal of reclamation, then deeper depths of topsoil or the use of a capillary barrier in conjunction with a topsoil covering may be used without compromising plant species richness.

\section{LITERATURE CITED}

Barth, R.C. 1983. Soil-depth requirements to reestablish perennial grasses on surface-mined areas in the northern Great Plains. Miner. Energ. Res. 27:1-20.

Barth, R.C. 1986. Reclamation technology for tailing impoundments. Part 2: revegetation. Miner. Energ. Res. 30:1-24.

Barth, R.C. 1988. Revegetation techniques for toxic tailing. Pages 55-68. In W.R. Keammerer and L.F. Brown (eds.). Proceedings-High Altitude Revegetation Workshop (no. 8). Colorado State University. Fort Collins, CO.

Barth, R.C. and B. Martin. 1981. Reclamation of phytotoxic tailing. Miner. Environ. 3: 55-65.

Bell, L.C., and J.R. Meecham. 1978. Reclamation of alumina refinery wastes at Gladstone, Australia. Rec. Review. 1:129-137. 
Berg, W.A., M.K. Kilkelly, and H.P. Harbert. 1983. Salt movement in a fine-textured processed oil shale under semi-arid conditions. Miner. Environ. 5:97-103.

Biondini, M.E., and E.F. Redente. 1986. Interactive effect of stimulus and stress on plant community diversity in reclaimed lands. Reclam. Reveg. Res. 4:211-222.

Chambers, J.C., R.W. Brown, and B.D. Williams. 1994. An evaluation of reclamation success on Idaho's phosphate mines. Res. Ecology. 2:4-16.

DePuit, E.J. 1984. Potential topsoiling strategies for enhancement of vegetation diversity on mined lands. Miner. Environ. 6:115-120.

DePuit, E.J. and J.G. Coenenberg. 1979. Methods for establishment of native plant communities on topsoiled coal stripmine spoils in the northern Great Plains. Rec. Review. 2:75-83.

Harbert, H.P. and W.A. Berg. 1978. Vegetative stabilization of spent oil shales. EPA 600/7-78-021. U.S. Environmental Protection Agency. Industrial Environmental Research Laboratory. Cincinnati, OH. $168 \mathrm{pp}$.

Harbert, H.P., W.A. Berg, and D.B. McWhorter. 1979. Lysimeter study on the disposal of Paraho retorted oil shale. EPA 600/7-79-188. U.S. Environmental Protection Agency. Industrial Environmental Research Laboratory. Cincinnati, OH. 170 pp.

Hargis, N.E., and E.F. Redente. 1984. Soil handling for surface mine reclamation. J. Soil and Water Cons. 39:300-305.

Huston, M. 1979. A general hypothesis of species diversity. Am. Nat. 113:81-101.

Jordan, J.E. and S.W. Dewar. 1985. Vegetation characterization of a taconite tailing basin in Minnesota. Pages 249-254. In 1985 Symposium on Surface Mining, Hydrology, Sedimentology, and Reclamation. University of Kentucky, Lexington, KY.

Mount, C.B. 1985. Revegetation of Paraho retorted oil shale. M.S. Thesis. Colorado State University, Ft. Collins, CO.

Newman, G.J. and E.F. Redente. 2001. Long-term plant community development as influenced by revegetation techniques. J. Range Manage. 54:717-724.

Power, J.F., F.M. Sandoval, R.E. Ries, and S.D. Merrill. 1981. Effects of topsoil and subsoil thickness on soil water content and crop production on a disturbed soil. Soil Sci. Soc. Am. J. 45:124-129.

Redente, E.F., and C.W. Cook. 1984. Ecological studies of natural and established ecosystems on energy related disturbances in Colorado. Prog. Rep. for U.S. Department of Energy. DE-A602-76EV04018. Range Sci. Dep., Colorado State Univ., Fort Collins.

Redente, E.F. and E.J. DePuit. 1988. Reclamation of drastically disturbed rangelands. Pages 559-584. In P.T. Tueller (ed.). Vegetation Science Applications for Rangeland Analysis and Management. Kluwer Academic Publishers. Boston, MA.

Redente, E.F., C.B. Mount, and W.J. Ruzzo. 1982. Vegetation composition and production as affected by soil thickness over retorted oil shale. Reclam. Reveg. Res. 1:109-122. 
Redente, E.F., T.B. Doerr, C.E. Grygiel, and M.E. Biondini. 1984. Vegetation establishment and succession on disturbed soils in northwest Colorado. Rec. Rev. Res. 3: 153-165.

Redente, E.F., T. McLendon, and W. Agnew. 1997. Influence of topsoil depth on plant community dynamics of a seeded site in northwest Colorado. Arid Soil Res. Rehab. 11: 139-149.

Redente, E.F., R.I. Barnhisel, and J.M. Hower. 2000. Reclamation of oil shale. In R.I. Barnhisel, W.L. Daniels, and R.G. Darmony (eds.). Reclamation of drastically disturbed lands. American Society of Agronomy. Madison, WI.

SAS Institute, 1998. SAS ® Proprietary Software Release 6.12 TS020. SAS Institute Inc. Cary, NC.

Schuman, G.E. and Power, J.F. 1981. Topsoil management on mined lands. J. Soil and Water Cons. 36:77-78.

Schuman, G.E., E.M. Taylor, Jr., F. Rauzi, and B.A. Pinchak. 1985. Revegetation of mined land: influence of topsoil depth and mulching method. J. Soil and Water Cons. 40:249-252.

Stark, J.M., and E.F. Redente. 1985. Soil-plant diversity relationships on a disturbed site in northwestern Colorado. Soil Sci. Soc. Am. J. 49:1028-1034.

Stark, J.M., and E.F. Redente. 1990. Plant uptake and cycling of trace elements in retorted oil shale disposal piles. J. Environ. Qual. 19:495-501.

Sydnor, R.S. 1999. An evaluation of long-term plant community development on topsoil treatments overlying retorted oil shale. M.S. Thesis. Colorado State University, Ft. Collins, CO.

Sydnor, R.S. and E.F. Redente. 2000. Long-term plant community development on topsoil treatments overlying a phytotoxic growth medium. J. Environ. Qual. 29:1778-1786.

Tiedeman, J.A and C. Terwilliger. 1978. Phyto-edaphic classification of the Piceance Basin. Colorado State Univ., Range Sci. Dep., Sci. Ser. 31, 265 pp.

Trlica, M.J., L.F. Brown, C.L. Jackson, and J. Jones. 1994. Depth of soil over molybdenum tailing as it affects plant cover, production, and metals uptake. Pages 119-144. In W.R. Keammerer and L.F. Brown (eds.). Proceedings-High Altitude Revegetation Workshop (no. 11). Colorado State University. Fort Collins, CO.

Walker, S.C., R. Stevens, S.B. Monsen, and K.R. Jorgensen. 1995. Pages 372-380. In B.A. Roundy, E.D. Durant, J.S. Haley, D.K. Mann (comps.). Proceedings: wildland shrub and arid land restoration symposium. Las Vegas, NV. USDA Forest Service General Technical Report no. 315. Intermountain Research Station. Ogden, UT. 